\title{
Efisiensi Relatif Usahatani Bawang Merah di Kabupaten Bantul dengan Pendekatan Data Envelopment Analysis (DEA)
}

\author{
Relative Efficiency of Red Onion Farming in Bantul Regency With Data \\ Envelopment Analysis (DEA) Approach
}

\author{
Marfin Lawalata $^{1}$, Dwidjono Hadi Darwanto ${ }^{2}$, dan Slamet Hartono ${ }^{2}$ \\ ${ }^{1}$ Mahasiswa S2 Ekonomi Pertanian, Fakultas Pertanian UGM \\ ${ }^{2}$ Staf Dosen Fakultas Pertanian UGM, Kampus Bulaksumur, Yogyakarta
}

\begin{abstract}
This study aims to determine the level of technical efficiency of red onion farming in Bantul regency and its determinant factors. Data Envelopment Analysis (DEA) with output oriented assumption was applied to measure efficiency score from each farms observed. It is followed by using the analysis of Ordinary Least Square regression (OLS) to analyze the factors which affects the level of technical efficiency of onion farming in Bantul regency. The results of research showed that the majority of red onion farming in Bantul regency is in the category of inefficient. Based on DEA-CRS calculations, there are 11 (18.33\%) red onion farming which has been efficient, while the calculations of DEA-VRS shows there are 18 (30\%) red onion farming which has been efficient. Land size, farmers' age, education and farming experience have a significant influence on the level of technical efficiency.
\end{abstract}

Key Words: Relative Efficiency, DEA

\section{INTISARI}

Penelitian ini bertujuan mengetahui tingkat efisiensi teknis usahatani bawang merah di Kabupaten Bantul dan faktor-faktor yang mempengaruhi. Metode penelitian menggunakan analisis DEA (Data Envelopment Analysis) dengan asumsi output oriented digunakan untuk mengukur skor efisiensi dari masing-masing usahatani yang diamati. Selanjutnya menggunakan analisis regresi Ordinary Least Squares (OLS) untuk menganalisis faktor-faktor yang mempengaruhi tingkat efisiensi teknis usahatani bawang merah di Kabupaten Bantul.. Hasil penelitian menunjukkan bahwa sebagian besar usahatani bawang merah di Kabupaten Bantul masuk dalam kategori inefisien. Berdasarkan perhitungan DEA-CRS, sebanyak 11 $(18,33 \%)$ usahatani bawang merah telah efisien, sedangkan dengan perhitungan DEA VRS sebanyak 18 (30\%) usahatani bawang merah telah efisien. Luas lahan, umur petani, pendidikan, dan pengalaman usahatani memiliki pengaruh dan signifikan terhadap tingkat efisiensi teknis

Kata Kunci : Efisiensi Relatif, DEA

\section{PENDAHULUAN}

Program kebijakan revitalisasi pertanian menitikberatkan pada program pengembangan agribisnis. Kegiatan pokok yang dilakukan dalam program pengembangan agribisnis salah satunya adalah pengembangan diversifikasi usahatani, melalui pengembangan komoditas usahatani bernilai tinggi untuk meningkatkan pendapatan dan nilai tambah bagi petani (Anonim, 2005). Komoditas hortikultura merupakan komoditas potensial yang mempunyai nilai ekonomi tinggi dan memiliki potensi untuk terus dikembangkan. Pengembangan usahatani dengan komoditas hortikultura bernilai tinggi diantaranya dengan mengembangkan usahatani bawang merah. Tanaman ini merupakan salah satu komoditas sayuran unggulan yang sejak lama telah diusahakan oleh petani secara intensif. Komoditas sayuran ini termasuk ke dalam kelompok rempah tidak bersubstitusi yang berfungsi sebagai bumbu penyedap makanan serta bahan obat tradisional (Deptan, 2007). Luas Panen, Produksi dan Produktivitas Bawang Merah di Kabupaten Bantul, dari tahun 2007 - 2011 secara lengkap pada tabel 1 . 
Tabel 1. Luas Panen, Produksi dan Produktivitas Bawang Merah di Kabupaten Bantul, Tahun 2007 $-2011$

\begin{tabular}{lccc} 
Tahun & Luas Panen $(\mathrm{Ha})$ & Produksi $($ Kwintal) & Produktivitas (Kwintal/Ha) \\
\hline 2007 & 1368 & 131,09 & 95,82 \\
2008 & 1273 & 151,45 & 118,97 \\
2009 & 1227 & 166,56 & 135,74 \\
2010 & 1723 & 178,01 & 103,00 \\
2011 & 939 & 117,95 & 125,61
\end{tabular}

Sumber : BPS Kabupaten Bantul, 2012

Tabel 1 menunjukan bahwa luas panen bawang merah pada tahun 2007 seluas 1.368 ha. Tahun 2008 dan 2009 masing-masing turun sebesar 6,59 persen dan 10,39 persen, naik sebesar 25,95 persen pada tahun 2010 dan turun sebesar 31,35 persen dibandingkan tahun 2007. Produksi bawang merah terus mengalami peningkatan dari tahun 2007 sampai dengan 2010 dan mengalami penurunan pada tahun 2011, sedangkan produktivitas pada tahun 2007 sebesar 95,82 $\mathrm{kw} / \mathrm{ha}$ dan meningkat menjadi $118,97 \mathrm{kw} / \mathrm{ha}$ pada tahun 2008 dan meningkat menjadi 135,74 kw/ha pada tahun 2009. Pada tahun 2010 mengalami penurunan menjadi 103,00 kw/ha dan mengalami peningkatan sebesar 125,61 kw/ha. Produksi bawang merah di Kabupaten Bantul mengalami fluktuasi setiap tahun dan berdasarkan data terakhir pada tahun 2011 produksi bawang merah mengalami penurunan.

Produktivitas bawang merah di Kabupaten Bantul pada tahun 2011 lebih tinggi dibandingkan produktivitas bawang merah di Daerah Istimewa Yogyakarta dan nasional. Berdasarkan data yang tersedia menunjukan bahwa produktivitas bawang merah di Kabupaten Bantul pada tahun 2011 sebesar 12,56 ton per hektar jumlah ini lebih tinggi dibandingkan produktivitas di Daerah Istimewa Yogyakarta yang hanya sebesar 11,34 ton per hektar. Produksi bawang merah secara nasional tahun 2011 sebesar 893.124 ribu ton, dengan luas panen sebesar 93.667 ribu hektar, dan rata-rata produktivitas sebesar 9,54 ton per hektar, nilai ini lebih kecil dibandingkan produktivitas bawang merah di Kabupaten Bantul. Dibandingkan tahun 2010, produksi menurun sebesar 155.810 ribu ton (14,85 persen). Penurunan disebabkan menurunnya produktivitas sebesar 0,03 ton per hektar (0,31 persen) dan penurunan luas panen seluas 15.967 ribu hektar (14,56 persen) (BPS, 2012).

Secara agregat produktivitas bawang merah di Kabupaten Bantul cukup tinggi, namun hal tersebut tidak berbanding lurus dengan produktivitas masing-masing petani karena tidak semua petani secara teknis efisien. Atau dengan kata lain bahwa tidak semua petani mampu memanfaatkan jumlah input minimum yang diperlukan untuk menghasilkan kuantitas output yang diinginkan dengan teknologi yang tersedia. Demikian pula, tidak semua petani mampu meminimalkan biaya yang diperlukan untuk produksi output yang dimaksudkan. Dari sudut pandang teoritis, petani tidak selalu mengoptimalkan fungsi produksi mereka. Adanya batasan produksi mencirikan jumlah minimum kombinasi input yang diperlukan untuk produksi beragam produk, atau output maksimum dengan kombinasi berbagai masukan dan teknologi tertentu. Petani yang beroperasi di atas batasan produksi dianggap secara teknis efisien, sementara mereka yang beroperasi di bawah batasan produksi secara teknis tidak efisien (Constantin $e t$ al, 2009).

\section{BAHAN DAN METODE}

Metode dasar yang digunakan adalah penelitian deskriptif analisis (Nazir, 1998). Jenis penelitian ini adalah survei dengan metode studi analisis eksplanatori. Penelitian dilakukan di Kabupaten Bantul. Penentuan lokasi penelitian dilakukan secara sengaja (Purposive), yaitu Kec. Sanden (Desa Srigading) \& Kec. Kretek (Desa Parangtritis). Penentuan sampel penelitian menggunakan teknik Quota Sampling yaitu dilakukan pemilihan secara tidak acak atau menurut kuota yang telah ditetapkan dan metode ini ada yang bersifat proportional dan non proportional. Dalam penelitian ini digunakan non proportional yaitu menentukan jumlah minimum dari unit-unit sampel dari suatu kategori. Pengambilan sampel petani, dilakukan secara simple random sampling. Sampel yang diambil memiliki informasi tentang usahatani bawang merah yang diperlukan oleh peneliti. Dan sampel yang diambil yaitu petani yang menanam tanaman 
bawang merah pada musim tanam pertama bulan Maret sampai dengan April tahun 2011 sebanyak 60 responden.

Untuk menjawab mengetahui tingkat efisiensi relatif usahatani bawang merah dianalisis dengan metode Data Envelopment Analysis (DEA). Model yang digunakan adalah DEA-CCR yang menggunakan pendekatan Constant Return to Scale dan Variable Return to Scale dengan orientasi output. Dan jumlah petani atau DMU sebanyak 60. TE diperoleh berdasarkan model linear programming berikut (Ali dan Seiford, 1993) :

$$
\begin{aligned}
& \operatorname{Max}_{\theta, \lambda} \theta_{i} \\
& \text { subject to } \sum_{j=1}^{n} \lambda_{j} y_{j}-\theta_{i} y_{i}-s=0 \\
& \sum_{j=1}^{n} \lambda_{j} x_{k j}+e_{k}=x_{k i} \\
& \lambda_{j} \geq 0 ; s \geq 0 ; e_{k}=0
\end{aligned}
$$

Di mana adalah kemungkinan peningkatan proporsi output untuk DMU ke-i (Decision Making Unit dalam penelitian ini adalah petani bawang merah), $\lambda_{\mathrm{j}}$ adalah vektor $\mathrm{Nx} 1$ bobot relatif terhadap efisien DMU, $s$ adalah output slack, dan $\mathrm{e}_{\mathrm{k}}$ adalah input slack variabel ke-i. Banker et al. (1984) menyarankan untuk mengadaptasi model DEA CRS dalam rangka untuk menjelaskan kembali situasi variabel skala. Dengan menambahkan konveksitas kendala N1' $\lambda$ $=1$, model dapat dimodifikasi ke VRS DEA. Peningkatan proporsional dalam output yang mungkin dicapai ketika output slack, yaitu s menjadi nol. Hasil dari suatu DMU efisien ketika nilai-nilai $\theta$ dan $\lambda_{i}$ sama dengan1, dan $\lambda_{j}=0$. Sebaliknya, DMU yang tidak efisien ketika $\theta>1$, $\lambda_{\mathrm{i}}=0$; dan $\lambda_{\mathrm{j}} \neq 0$. Pemecahan (1) kita dapat memperoleh ukuran TE yang mencerminkan "jarak" antara diamati dan hasil produksi yang optimal untuk jumlah input tertentu:

$$
T E=\frac{Y_{i}}{Y_{i}^{*}}=\frac{1}{\theta_{i}} \quad 0 \leq T E_{i} \leq 1
$$

Dimana $\mathrm{Y}_{\mathrm{i}}$ dan $\mathrm{Y}_{\mathrm{i}}^{*}$ adalah kemungkinan masing-masing output maksimum (optimal) dengan membandingkan skor $\mathrm{TE}^{\mathrm{CRS}}$ dan $\mathrm{TE}^{\mathrm{VRS}}$. Selisih antara dua nilai TE menunjukkan ada skala inefisiensi yang membatasi pencapaian skala (konstan) yang optimal:

$T E_{i}^{C R S}=T E_{i}^{V R S} * S E_{i}$
Oleh karena itu, dapat dihitung sebagai (Coelli 1996) :

$S E_{i}=\frac{T E^{C R S}}{T E^{V R S}} \quad 0 \leq S E_{i} \leq 1$

Dimana $\mathrm{SE}_{\mathrm{i}}=1$ menunjukkan skala efisiensi penuh dan $\mathrm{SE}_{\mathrm{i}}<1$ menunjukkan adanya skala inefisiensi. Namun, kelemahan dari skor SE adalah bahwa hal itu tidak menunjukkan apakah sebuah usahatani beroperasi dibawah decreasing atau increasing return to scale. Hal ini diatasi dengan hanya non-increasing return to scale (NIRS) sesuai kondisi dalam model DEA, yaitu mengubah konveksitas kendala $\mathrm{N} 1{ }^{\prime} \lambda=1$ dari model DEA VRS ke N1' $\lambda \leq 1$. Jika TE ${ }^{\text {NIRS }}$ dan $\mathrm{TE}^{\mathrm{VRS}}$ tidak sama, maka usahatani beroperasi di bawah increasing return to scale (IRS), jika keduanya sama berarti usahatani ada yang beroperasi dengan decreasing return to scale (Madau, 2012).

Skor efisensi relatif tiap DMU diidentifikasi dengan perhitungan DEA-CCR yang menggunakan pendekatan constant return to scale (CRS) dengan pendekatan output-oriented. Secara umum, DMU mempertimbangkan menjadi efisien jika menghasilkan skor 1 dan jika skor kurang dari 1 implikasi bahwa tidak efisien. Analisis dengan model output oriented, hasilnya adalah petani efisien berarti mampu mengkombinasikan input dan output secara efisien untuk mencapai output yang ditetapkan. Perhitungan data dengan metode DEA dalam penelitian ini tidak dilakukan secara manual tetapi menggunakan software DEAP Version 2.1 untuk mengukur efisiensi usahatani bawang merah.

Untuk menjawab tujuan tentang faktorfaktor yang mempengaruhi tingkat efisiensi teknis usahatani bawang merah di Kabupaten Bantul, digunakan software Eviews Ver. 6 dengan meregresi variabel independent dalam hal ini variabel sosial berupa luas lahan usahatani, umur petani, pendidikan formal petani, pengalaman usahatani dan jumlah tanggungan keluarga petani terhadap variabel dependen yaitu nilai technical efficiency (TE) yang diperoleh dari hasil analisis efisiensi usahatani bawang merah dengan program Data Envelopment Analysis (DEA) dengan asumsi Constant Return to Scale (CRS). berikut :
Model persamaaan regresinya sebagai 
$T E=\delta_{0} L_{-} L a h a n^{\delta 1} U_{-}$Petani $^{\delta 2}$ Pendk $^{\delta 3} P_{-} U_{s t a n}{ }^{\delta 4} \mathrm{JmlTgKlg}^{\delta 5}$

Dalam bentuk ln dapat dituliskan sebagai berikut :

$$
\begin{aligned}
\ln T E= & \delta_{0}+\delta_{1} \ln L_{-} L a h a n+\delta_{2} \ln U_{-} \text {Petani }+\delta_{3} \ln \text { Pendk }+\delta_{4} \ln P_{-} \text {Ustan }+ \\
& \delta_{5} \ln \mathrm{Jm} \operatorname{T} \mathrm{Tg} \text { Klg }
\end{aligned}
$$

Keterangan :

$T E$

U_Petani

Pendk

P_Ustan

JmlTgKlg
= nilai technical efficiency dari hasil analisis DEA asumsi CRS

= luas lahan (ha)

$=$ umur petani (thn)

$=$ pendidikan petani $($ thn $)$

= pengalaman berusahatani (thn)

= tanggungan keluarga (orang) $\delta_{0} \quad=$ intersep

$\delta_{1}=$ koefisien regresi luas lahan

$\delta_{2}=$ koefisien regresi umur petani

$\delta_{3}=$ koefisien regresi pendidikan petani

$\delta_{4}=$ koefisien regresi pengalaman berusahatani

$\delta_{5}=$ koefisien regresi jumlah tanggungan keluarga

\begin{tabular}{|c|c|c|c|c|c|c|c|c|}
\hline \multirow[t]{2}{*}{ DMU } & Output & \multicolumn{7}{|c|}{ Input } \\
\hline & $\begin{array}{c}\text { Produksi } \\
\text { Bawang } \\
\text { Merah } \\
(\mathrm{Kg})\end{array}$ & $\begin{array}{c}\text { Luas } \\
\text { Lahan } \\
\text { (Ha) }\end{array}$ & $\begin{array}{c}\text { Jumlah } \\
\text { Benih } \\
(\mathrm{Kg})\end{array}$ & $\begin{array}{c}\text { Jumlah } \\
\text { Pupuk } \\
\text { Organik } \\
(\mathrm{Kg}) \\
\end{array}$ & $\begin{array}{c}\text { Jumlah } \\
\text { Pupuk } \\
\text { Phonska } \\
(\mathrm{Kg}) \\
\end{array}$ & $\begin{array}{c}\text { Jumlah } \\
\text { Fungisida } \\
\text { Padat } \\
(\mathrm{Kg}) \\
\end{array}$ & $\begin{array}{c}\text { Jumlah } \\
\text { Insektisida } \\
\text { Cair (l) }\end{array}$ & $\begin{array}{c}\text { Jumlah } \\
\text { Tenaga } \\
\text { Kerja } \\
\text { (HOK) } \\
\end{array}$ \\
\hline 1 & $\ldots$ & $\ldots$. & $\ldots$ & $\ldots$ & $\ldots$ & $\ldots$ & $\ldots$ & $\ldots$ \\
\hline 2 & .... & .... & .... & $\ldots$. & .... & $\ldots$ & $\ldots$ & $\ldots$ \\
\hline$:$ & $:$ & $:$ & $:$ & $:$ & $:$ & $:$ & $:$ & $:$ \\
\hline$:$ & $:$ & $:$ & $:$ & $:$ & : & : & $:$ & : \\
\hline$:$ & $:$ & $:$ & : & $:$ & $:$ & : & $:$ & : \\
\hline 60 & $\ldots$ & $\ldots$ & $\ldots$ & $\ldots$ & $\ldots$. & $\ldots$. & $\ldots$ & $\ldots$ \\
\hline
\end{tabular}

Tabel 2. Konsep dasar DEA dengan output produksi bawang merah $(Y)$

Sumber : Coelli, 1996

\section{HASIL DAN PEMBAHASAN}

Perhitungan dilakukan dengan menggunakan software DEAP Version 2.1 untuk menentukan efisiensi usahatani bawang merah menggunakan variabel input yaitu luas lahan, jumlah benih, jumlah pupuk organik, jumlah pupuk phonska, jumlah fungisida padat, jumlah insektisida cair, jumlah tenaga kerja, sedangkan variabel output adalah produksi bawang merah. Variabel input dan output diperoleh dari hasil wawancara dengan petani bawang merah. Hasil analisis efisiensi relatif usahatani bawang merah di Kabupaten Bantul disajikan pada tabel berikut ini.

Tabel 3. Estimasi Efisiensi Teknis dan Skala Efisiensi dengan DEA

\begin{tabular}{cccc}
\hline Efisiensi & TE $^{\text {CRS }}$ & TE $^{\text {VRS }}$ & SE \\
\hline Mean & 0,467 & 0,665 & 0,687 \\
s.d & 0,326 & 0,327 & 0,269 \\
Min & 0,005 & 0,017 & 0,112 \\
Max & 1,000 & 1,000 & 1,000 \\
\hline
\end{tabular}

Sumber : Hasil Analisis DEA, 2012

Berdasarkan tabel 3, rata-rata efisiensi usahatani bawang merah dengan menggunakan asumsi Constant Return To Scale (CRS) adalah 0,467 . Perhitungan ini menghasilkan 11 usahatani bawang merah $(18,67$ persen $)$ yang telah beroperasi secara efisien dan 49 usahatani bawang merah $(81,67$ persen $)$ belum beroperasi secara efisien (inefisien) pada musim tanam pertama tahun 2011. Usahatani bawang merah dengan nilai efisiensi terendah adalah usahatani bawang merah DMU ke -1 di Desa Parangtritis dengan nilai efisiensi sebesar 0,005. Perhitungan efisiensi usahatani bawang merah menggunakan asumsi Variable Return To Scale (VRS) menghasilkan 
nilai rata-rata efisiensi sebesar 0,665 . Perhitungan ini menghasilkan 18 usahatani bawang merah (30 persen) yang telah beroperasi secara efisien dan 42 usahatani bawang merah (70 persen) belum beroperasi secara efisien selama musim tanam pertama tahun 2011. Usahatani bawang merah dengan nilai efisiensi terendah menurut asumsi ini adalah DMU ke-1 di Desa Parangtritis dengan nilai efisiensi sebesar 0,017 . Inefisiensi usahatani bawang merah menunjukan bahwa masih terdapat output yang belum optimal dicapai pada periode penelitian dalam pemanfaatan input (sumberdaya) yang dapat dilihat pada gambar 1.

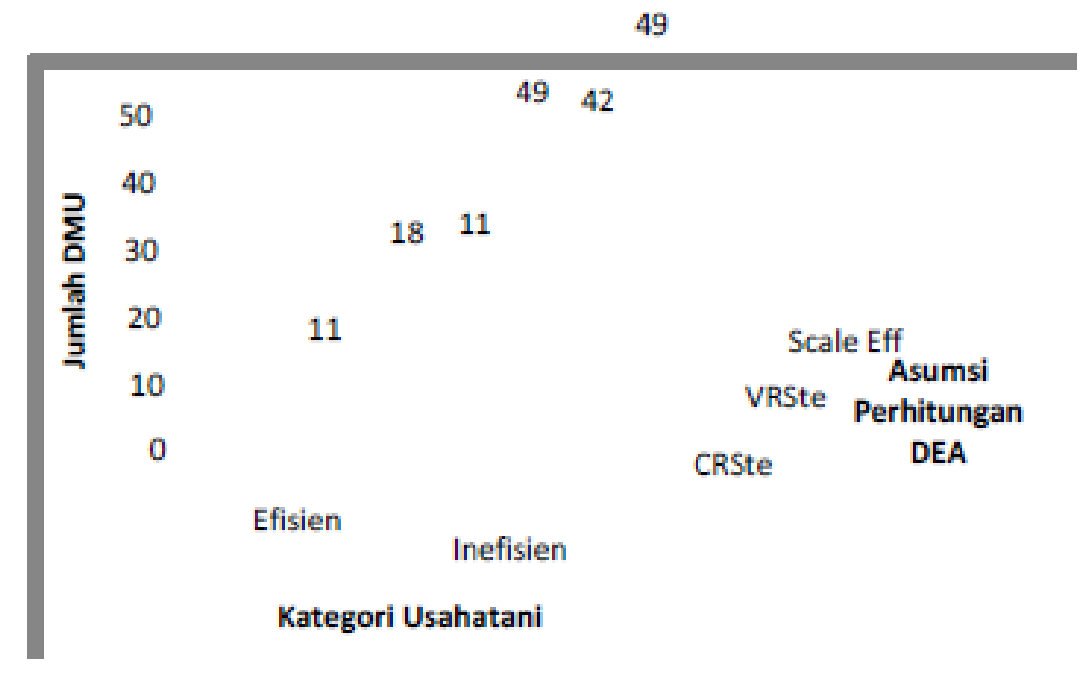

Gambar 1. Kategori Efisiensi Usahatani Bawang Merah di Kabupaten Bantul

Dari gambar diatas perhitungan technical efficiency dengan metode Constant Return to Scale (CRS) dimana proporsi penambahan input dan output sebanding atau tetap menghasilkan usahatani bawang merah yang efisien lebih sedikit dibandingkan perhitungan dengan asumsi Variable Return to Scale (VRS) dimana proporsi penambahan jumlah input dan output tidak sebanding atau berubah-ubah. Sedangkan perbandingan antara asumsi CRS dan VRS menghasilkan skala efisiensi. Terlihat bahwa berdasarkan skala efisiensi jumlah usahatani bawang yang efisien lebih sedikit dibandingkan usahtani yang efisien. Hasil perhitungan DEA dengan menggunakan asumsi VRS dapat diketahui posisi return to scale (RTS) dari usahatani bawang merah yang diamati, yaitu apakah pada posisi increasing return to scale (IRS), constant return to scale (CRS) atau decreasing return to scale (DRS).

Tabel 4. Skala efisiensi dan return to scale dari DEA

\begin{tabular}{cccc}
\hline & Observasi (jumlah n) & Persentase (\%) & Skala Efisiensi \\
\hline Total Sampel & 60 & 100,00 & 0,687 \\
Decreasing Return to Scale & 41 & 68,33 & 0,606 \\
Constant Return to Scale & 11 & 18,33 & 1,000 \\
Increasing Return to Scale & 8 & 13,34 & 0,669 \\
\hline
\end{tabular}

Sumber : Hasil Analisis DEA, 2012

Hasil perhitungan dengan metode DEA menunjukan nilai RTS yang sebagian besar usahatani bawang merah saat ini pada posisi diseconomics of scale, hal ini ditunjukan dengan indikator sebanyak 41 usahatani bawang merah (68,33 persen) berada pada posisi decreasing (Supra-optimal) return to scale, 11 usahatani bawang merah berada pada posisi constant return to scale atau optimal scale dan hanya 8 usahatani bawang merah yang mengalami increasing return to scale atau sub optimal scale (gambar 2). Hasil analisa tersebut mempunyai makna bahwa saat ini usahatani bawang merah harus mengurangi jumlah input yang ada untuk mencapai efisiensi.

Pengalokasian input yang tidak tepat menjadi penyebab utama timbulnya inefisiensi dalam usahatani bawang merah. Apabila input yang digunakan berlebihan atau terlalu sedikit maka akan menyebabkan petani tidak efisien. Kombinasi input yang tepat sangat penting dalam 
usahatani bawang merah yang memiliki risiko tinggi, apabila sudah mencapai full efficiency maka pada gilirannya akan memberikan pendapatan yang maksimal untuk petani. Masih banyaknya petani yang berada pada decreasing return to scale menandakan alokasi penggunaan input tidak tepat sehingga cenderung akan menurunkan hasil dan membuat biaya usahatani bawang merah makin besar, dan kurang lebih ada 8 usahatani bawang merah yang masih berada pada increasing return to scale, artinya dengan menambah jumlah input tertentu usahatani bawang merah mampu mencapai efisiensi penuh, karena petani enggan menangggung risiko maka petani tersebut cenderung berhati-hati dalam penggunaan input, namun input yang dialokasikan mempengaruhi tingkat efisiensi usahatani tersebut, dan ada 11 petani bawang merah yang sudah efisien dalam mengalokasikan input sehingga berada pada kondisi constant return to scale.

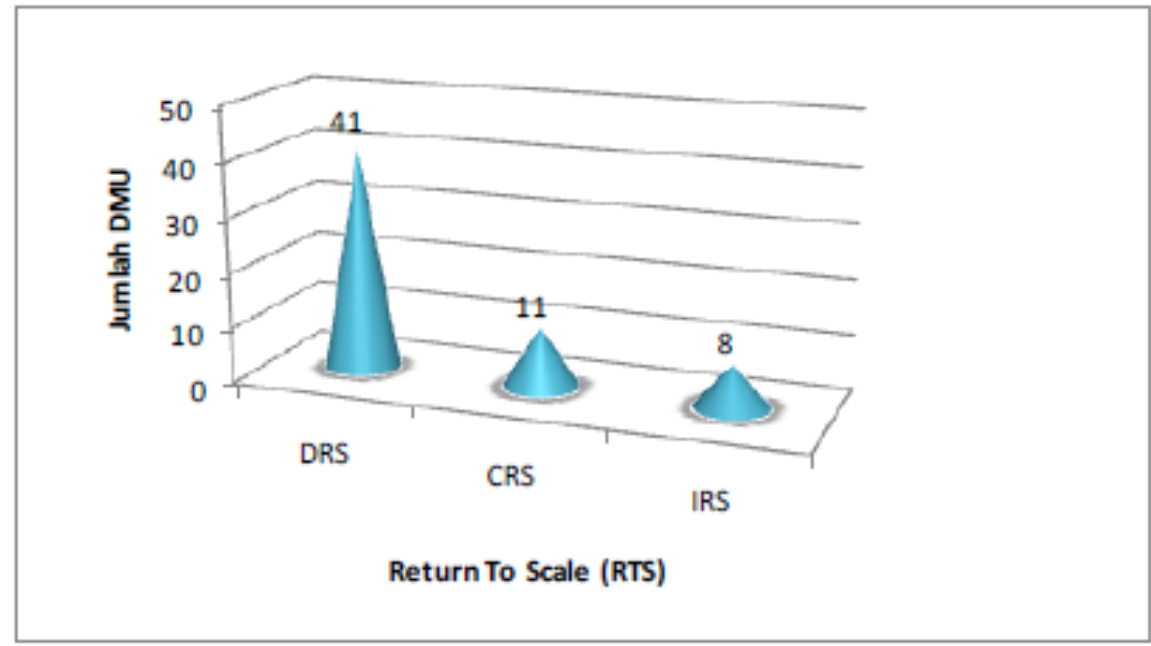

Gambar 2. Kategori RTS Usahatani Bawang Merah di Kabupaten Bantul

Disamping adanya faktor-faktor yang secara signifikan mempengaruhi output atau produksi bawang merah terdapat pula faktorfaktor sosial yang mempengaruhi efisiensi usahatani bawang merah pada musim tanam pertama tahun 2011. Faktor-faktor tersebut adalah luas lahan, umur petani, pendidikan formal petani, pengalaman usahatani dan jumlah anggota keluarga. Tujuan dilakukan analisis regresi adalah menganalisis faktor sosial yang mempengaruhi technical efficinecy (TE) melalui fungsi produksi Cobb-Douglas. Hasil analisis fungsi produksi Cobb-Douglas secara lengkap dapat dilihat pada tabel berikut ini.

Tabel 5. Hasil Analisis Regresi Faktor-faktor yang Mempengaruhi Tingkat Efisiensi Teknis Usahatani Bawang Merah

\begin{tabular}{lccccc}
\hline \multicolumn{1}{c}{ Variabel } & $\begin{array}{c}\text { Tanda } \\
\text { Harapan }\end{array}$ & $\begin{array}{c}\text { Koefisien } \\
\text { Regresi }\end{array}$ & t-hitung & Probabilitas & Signifikan \\
\hline C & $+/-$ & $-8,8817$ & $-3,4642$ & 0,0010 & $* * *$ \\
Luas Lahan & $+/-$ & 0,4039 & 2,2976 & 0,0255 & $* *$ \\
Umur Petani & $+/-$ & 1,2668 & 2,0897 & 0,0414 & $* *$ \\
Pendidikan & + & 0,9309 & 2,2747 & 0,0269 & $* *$ \\
Pengalaman & + & 0,5268 & 2,1376 & 0,0371 & $* *$ \\
Jumlah Tanggungan & + & 0,1275 & 0,5172 & 0,6071 & $\mathrm{~ns}$ \\
\hline R-squared & 0,4624 & $* * *$ : Signifikan pada tingkat kesalahan 1 \% & \\
F-statistic & 9,2904 & $* *$ : Signifikan pada tingkat kesalahan 5\% & \\
& & $*$ & : Signifikan pada tingkat kesalahan 10\% & \\
& & : Tidak Signifikan &
\end{tabular}

Sumber : Analisis Data Primer, 2012 
Berdasarkan hasil analisis pada tabel 5, diketahui bahwa nilai koefisien determinasi $\left(\mathrm{R}^{2}\right)$ sebesar 0,4624. Hal ini berarti sebanyak 46,24 persen variasi dari technical efficinecy (TE) produksi bawang merah pada musim tanam pertama dapat dijelaskan oleh variasi variabel independen dalam model. Hasil uji menunjukan bahwa nilai $F$ hitung sebesar 9,2903 lebih dari $F$ tabel $(1,2368)$ berarti bahwa variabel independen secara bersama sama berpengaruh nyata terhadap nilai technical efficinecy (TE).

Hasil uji $t$ terhadap variabel independen yang berpengaruh nyata (significant) terhadap technical efficinecy (TE) adalah luas lahan, umur petani, pendidikan dan pengalaman usahatani. Dan variabel jumlah tanggungan keluarga tidak berpengaruh nyata terhadap technical efficinecy (TE) usahatani bawang merah pada musim tanam pertama (MT I). Koefisien regresi luas lahan, umur petani, pendidikan dan pengalaman usahatani bertanda positif. Berarti setiap penambahan variabel sosial tersebut akan meningkatkan nilai technical efficinecy (TE) usahatani bawang merah pada musim tanam pertama (MT I) mendekati atau mencapai full efficiency. Berikut dapat dijelaskan faktor-faktor produksi yang terhadap nilai technical efficinecy (TE) usahatani bawang merah.

\section{Luas lahan}

Variabel luas lahan merupakan salah satu variabel yang berpengaruh nyata (significant) terhadap efisiensi teknis usahatani bawang merah pada tingkat kepercayaan 95 persen $(\alpha=0,05)$ dan memiliki koefisien regresi sebesar 0,4038 serta bertanda positif. Hal ini berarti jika luas lahan usahatani bawang merah bertambah 1 persen akan meningkatkan efisiensi teknis sebesar 0,4038 persen. Jika luas lahan ditambah maka usahatani bawang merah semakin efisien. Peningkatan luas lahan usahatani tanpa diikuti dengan penggunaan input yang tepat prinsip manajemen yang baik, luas lahan akan menjadi faktor penghambat dalam peningkatan efisiensi teknis usahatani bawang merah di Kabupaten Bantul.

\section{Umur Petani}

Salah satu variabel sosial yang berpengaruh nyata terhadap nilai technical efficinecy (TE) usahatani bawang merah adalah variabel umur petani, dimana dengan tingkat kepercayaan sebesar 95 persen $(\alpha=0,05)$ dan koefisien regresi sebesar 1,2668. Hal ini berarti jika umur petani bawang merah bertambah 1 persen akan meningkatkan efisiensi teknis sebesar
1,2668 persen. Umur petani responden pada usahatani bawang merah berpengaruh nyata atau signifikan terhadap nilai technical efficinecy (TE) dengan hubungan arah yang positif. Umur petani memiliki koefisien regresi yang nilai elastisitasnya lebih dari satu, sehingga kenaikan umur petani satu persen mampu meningkatkan efisiensi teknis lebih dari satu persen. Hal ini dapat diartikan semakin tinggi umur petani maka semakin banyak pengalaman yang dimiliki sehingga petani tersebut semakin efisien dalam menjalankan usahatani.

\section{Pendidikan}

Selain variabel umur petani yang berpengaruh nyata, variabel pendidikan juga berpengaruh nyata terhadap nilai technical efficinecy (TE) usahatani bawang merah adalah variabel umur petani, dimana dengan tingkat kepercayaan sebesar 95 persen $(\alpha=5 \%)$ dan koefisien regresi sebesar 0.9309. Pendidikan formal petani bawang merah berpengaruh nyata atau signifikan terhadap nilai technical efficinecy (TE) dengan hubungan arah yang positif. Hal ini berarti jika pendidikan bawang merah bertambah 1 persen akan meningkatkan efisiensi teknis sebesar 0,9309 persen Dengan demikian dapat diartikan semakin tinggi tingkat pendidikan petani maka petani tersebut semakin efisien dalam menjalankan usahatani atau semakin tinggi tingkat pendidikan petani, maka semakin kecil peluang petani tersebut melakukan ketidakefisienan.

4. Pengalaman Usahatani

Selain variabel umur petani dan pendidikan, variabel yang berpengaruh nyata terhadap nilai technical efficinecy (TE) usahatani bawang merah adalah pengalaman usahatani, dimana dengan tingkat kepercayaan sebesar 95 persen $(\alpha=5 \%)$ dan koefisien regresi sebesar 0.5267. Pengalaman petani bawang merah berpengaruh nyata atau signifikan terhadap nilai technical efficinecy (TE) dengan hubungan arah yang positif. Hal ini berarti jika pengalaman usahatani bawang merah bertambah 1 persen akan meningkatkan efisiensi teknis sebesar 0,5267 persen. Dengan demikian dapat diartikan semakin banyak pengalaman usahatani petani maka petani tersebut semakin efisien dalam menjalankan usahatani bawang merah yang dimilikinya. Variabel lain yang diduga mempengaruhi efisiensi teknis usahatani bawang merah adalah jumlah tanggungan keluarga memiliki t-hitung yang lebih kecil dari ttabel. Hal tersebut berarti bahwa variabel jumlah tanggungan keluarga tidak berpengaruh (non 
significant) terhadap nilai efisiensi teknis usahatani bawang merah di Kabupaten Bantul.

\section{KESIMPULAN}

1. Sebagian besar usahatani bawang merah di Kabupaten Bantul belum efisien. Usahatani dengan nilai efisiensi terendah berada di Desa Parangtritis, Kecamatan Kretek. Secara garis besar perhitungan efisiensi dengan menggunakan metode Data Envelopment Analysis (DEA) dengan orientasi output, asumsi VRS menghasilkan jumlah usahatani yang efisien lebih banyak dari yang inefisien demikian hal juga dengan nilai rata-rata Technical Efisiensi (TE), dan faktor-faktor yang mempengaruhi efisiensi teknis usahatani bawang merah di Kabupaten Bantul adalah luas lahan, umur petani, pendidikan dan pengalaman usahatani.

2. Pada musim tanam pertama (MT I) tahun 2011 usahatani bawang merah di Kabupaten Bantul berada pada keadaan diseconomics of scale karena banyaknya petani yang berada pada Decreasing Return To Scale (DRS), sehingga kedepannya dalam menjalankan usahatani bawang merah untuk mencapai full efficiency petani harus mengurangi jumlah input yang sudah melebihan anjuran.

\section{DAFTAR PUSTAKA}

Ali, A.I. and L.M. Seiford. 1993. Computational Accuracy and Infinitesimals in Data Envelopment Analysis. INFOR 31(4): 290297.

Anonim. 2005. Peraturan Presiden Republik Indonesia Nomor 7 Tahun 2005, Tentang : Rencana Pembangunan Jangka Menengah Nasional Tahun 2004 - 2009. CV. Eka Jaya. Jakarta.

Badan Pusat Statistik. 2012. Luas Panen, Produksi, dan Produktivitas Bawang Merah Indonesia Tahun 2011. www.bps.go.id/ diakses tanggal 13 Juli 2012.

.2012. Statistik Daerah Kabupaten Bantul Tahun 2012. Bantul. D.I. Yogyakarta.

Banker, R.D., Charnes A., and Cooper W.W. 1984. Some Models for Estimating Technical and Scale Inefficiency in Data Envelopment Analysis. Management Science 30: 10781092.
Departemen Pertanian. Jakarta. 2007. Perkembangan Tanaman Pangan dan Hortikultura. Departemen Pertanian. Jakarta.

Coelli, T.J., D.S.P. Rao., C.J. O'Donnel., dan G.E. Battase. 2005. An introduction to Efficiency and Productivity Analysis. 2nd edition. Springger Science. New York. p 350.

Constantin, P.D., Martin D. L., Rivera. 2009. Cobb-Douglas, Translog Stochastic Production Function and Data Envelopment Analysis in Total Factor Productivity in Brazilian Agribusiness. The Flagship Research Journal of International Conference $O f$ the Production and Operations Management Society Volume 2, Number 2.

Madau, F. A. 2012. Technical and Scale Efficiency in Italian Citrus Farming : A Comparison between Stochastik Frontier Analysis (SFA) and Data Envelopment Analysis (DEA) Models. Munich Personal RePEc Archieve (MPRA) Paper No. 41403. University of Sassari. Italy.

Nazir, 1998. Metode Penelitian. Ghalia Indonesia. Balai Pustaka Aksara. Jakarta. 